\title{
Molecular identification and virulence of three Aeromonas hydrophila isolates cultured from infected channel catfish during a disease outbreak in west Alabama (USA) in 2009
}

\author{
Julia W. Pridgeon*, Phillip H. Klesius \\ Aquatic Animal Health Research Unit, USDA-ARS, 990 Wire Road, Auburn, Alabama 36832, USA
}

\begin{abstract}
Three isolates (AL09-71, AL09-72, and AL09-73) of Aeromonas hydrophila were cultured from infected channel catfish Ictalurus punctatus during a disease outbreak in west Alabama, USA, in August 2009. Sequence analysis of the 16S-23S rDNA intergenic spacer region (ISR), cpn60, gyrB, and rpoD genes of the 3 strains revealed that the 3 strains were closely related to each other, sharing 97 to $99 \%$ nucleotide sequence similarities. However, ISR sequences of the 3 isolates from 2009 shared only $64 \%$ nucleotide sequences with AL98-C1B, a 1998 isolate of A. hydrophila cultured from diseased fish in Alabama. Sequences of $c p n 60$, gyrB, and $r p o D$ from the 3 isolates from 2009 shared 91 to $95 \%$ homologies with AL98-C1B. Based on both $\mathrm{LD}_{50}$ and $\mathrm{LD}_{95}$ values of intraperitoneal injection assays, the virulences of the 3 isolates from 2009 were not significantly different from each other, but were at least 200-fold more virulent than AL98-C1B, indicating that the 3 west Alabama isolates of $A$. hydrophila from 2009 were highly virulent to channel catfish.
\end{abstract}

KEY WORDS: Aeromonas hydrophila $\cdot$ Molecular analysis $\cdot$ Virulence $\cdot$ Channel catfish

\section{INTRODUCTION}

Aeromonas hydrophila, a Gram-negative motile bacillus widely distributed in aquatic environments, is a causative agent of motile aeromonad septicemia (MAS) (Harikrishnan et al. 2003), also known as epizootic ulcerative syndrome (EUS) (Mastan \& Qureshi 2001). The symptoms of $A$. hydrophila infections include swelling of tissues, dropsy, red sores, necrosis, ulceration, and hemorrhagic septicemia (Karunasagar et al. 1989, Azad et al. 2001). Fish species affected by MAS include tilapia (Abd-El-Rhman 2009, TellezBañuelos et al. 2010), catfish (Majumdar et al. 2007, Ullal et al. 2008), goldfish (Irianto et al. 2003, Harikrishnan et al. 2009), common carp (Jeney et al. 2009, Yin et al. 2009), and eel (Esteve et al. 1994). Although usu- ally considered as a secondary pathogen associated with disease outbreaks, A. hydrophila could also become a primary pathogen in some environments, causing outbreaks in fish farms with high mortality rates and severe economic losses to the aquaculture industry worldwide (Thorpe \& Roberts 1972, Nielsen et al. 2001, Fang et al. 2004).

Between June and October 2009, a disease outbreak occurred in 48 catfish farms in west Alabama, USA, causing an estimated loss of more than 3 million pounds (ca. 1339 metric tons) of food size channel catfish Ictalurus punctatus (Hemstreet 2010). The disease produced a variety of symptoms that included sores on the skin, bulging eyes, ulcers, and bright red muscles and internal organs. Bacteria were cultured from diseased catfish, isolated, and later reported to be Aeromonas 
hydrophila (Hemstreet 2010). However, identification evidence was not shown in that short report.

Sequencing of the 16S-23S rDNA intergenic spacer region (ISR) is now considered a robust and sensitive taxonomic tool which is widely used in bacterial taxonomy (Martínez-Murcia et al. 2005, Tazumi et al. 2009). Gene sequences of $60 \mathrm{kDa}$ chaperonin (cpn60), DNA gyrase B subunit $(g y r B)$, and RNA polymerase sigma factor $(R p o D / r p o D)$ have also been used in previous studies to identify Aeromonas species (Miñana-Galbis et al. 2010). Three A. hydrophila isolates from 2009 and isolate AL98-C1B (collected in Alabama in 1998) were compared at the molecular level using the aforementioned 4 genes. The virulence of all 4 isolates against channel catfish was also compared.

\section{MATERIALS AND METHODS}

Bacterial strain isolation, identification, and growth conditions. Three isolates of Aeromonas hydrophila were collected from diseased food size channel catfish in August 2009 from west Alabama, USA. A. hydrophila isolate AL98-C1B was isolated from diseased channel catfish in Alabama in 1998. All 4 isolates were cultured on tryptic soy agar (TSA) plates according to published procedures (Panangala et al. 2007). Isolates of A. hydrophila were then determined by standard biochemical tests as described by Holt et al. (1994) and confirmed by API 20 E strip tests (BioMerieux USA) and fatty acid methyl ester analysis by the MIDI microbial identification gas chromatography system. All 4 isolates were maintained on TSA plates or in tryptic soy broth (TSB, Difco) at $28^{\circ} \mathrm{C}$ for 18 to $24 \mathrm{~h}$.

Genomic DNA extraction and polymerase chain reaction (PCR). Genomic DNA was extracted from pure bacterial cells using a DNeasy Kit (Qiagen) and quantified on a NanoDrop ND-1000 spectrophotometer (Nanodrop Technologies). Gene-specific primers were then designed to amplify regions of 4 genes: 16S-23S rDNA ISR, cpn60, gyrB, and rpoD. Primer se- quences used in PCR are listed in Table 1. PCR was performed in a $10 \mu \mathrm{l}$ mixture consisting of $5 \mu \mathrm{l}$ of Taq PCR Master Mix (Qiagen), $3 \mu$ l of nuclease-free $\mathrm{H}_{2} \mathrm{O}$, $1 \mu \mathrm{l}$ of Aeromonas hydrophila genomic DNA (10 ng $\left.\mu^{-1}\right), 0.5 \mu \mathrm{l}$ of forward primer $(5 \mu \mathrm{M})$, and $0.5 \mu \mathrm{l}$ of reverse primer $(5 \mu \mathrm{M})$. All PCRs were carried out in a Biometra T Gradient thermocycler. The PCR reaction conditions consisted of an initial denaturation step at $94^{\circ} \mathrm{C}$ for $5 \mathrm{~min}$ followed by 35 cycles of $30 \mathrm{~s}$ at $94^{\circ} \mathrm{C}$, $30 \mathrm{~s}$ at $53^{\circ} \mathrm{C}$, and $1 \mathrm{~min}$ at $72^{\circ} \mathrm{C}$, followed by a final extension of $10 \mathrm{~min}$ at $72^{\circ} \mathrm{C}$ and maintained at $4^{\circ} \mathrm{C}$.

Sequencing and sequence analysis. PCR products were verified by electrophoresis on a $1 \%$ agarose gel stained with ethidium bromide. PCR products were then purified using a PCR DNA purification kit (GE health care) according to the manufacturer's protocol and sent to USDA-ARS Mid South Genomic Laboratory (Stoneville, MS) for sequencing with an ABI 3730 Genetic Analyzer (Applied Biosystems). The amplification primers listed in Table 1 were used for the forward and reverse sequencing. Sequences were analyzed using the National Center for Biotechnology Information (NCBI) BLAST program to search for sequence homologies.

Virulence of 4 Aeromonas hydrophila isolates to channel catfish. All $4 \mathrm{~A}$. hydrophila isolates were grown in TSB (Difco) at $28^{\circ} \mathrm{C}$ for 18 to $24 \mathrm{~h}$. The concentration (colony forming units [CFU] $\mathrm{ml}^{-1}$ ) of A. hydrophila used in this study was determined through serial dilutions. An optical density (OD) of 1.0 of the bacterial cultures was measured at $540 \mathrm{~nm}$ using a thermospectronic spectrophotometer (Fisher Scientific). At least 5 different dilutions of the $\mathrm{OD}=1.0$ overnight bacterial culture for each isolate was used to inject fish. The OD $=1.0$ bacterial cultures were then stored at $4^{\circ} \mathrm{C}$ for later plate counting. Soon after the fish were injected by different dilutions of bacteria ( $<1 \mathrm{~h})$, serial dilutions (in triplicate) of each A. hydrophila isolate were prepared in TSB, and $100 \mu \mathrm{l}$ of each dilution were plated onto TSA plates. After $24 \mathrm{~h}$ incubation at $28^{\circ} \mathrm{C}$, the average number of $\mathrm{CFU} \mathrm{ml}{ }^{-1}$ was

Table 1. Primers used in PCR amplification and sequencing of 16S-23S rDNA ISR (16S ISR), 60 kDa chaperonin (cpn60), DNA gyrase B subunit $(g y r B)$, and RNA polymerase sigma factor (rpoD) genes

\begin{tabular}{|lcccc|}
\hline \multirow{2}{*}{ Gene } & Accession no. & Primer name & Primer sequence $\left(5^{\prime}-3^{\prime}\right)$ & Melting temp. $\left({ }^{\circ} \mathrm{C}\right)$ \\
\hline 16S ISR & NC_008570 & 16S-Forward & CACGGTGTGATTCATGACTGG & 66.50 \\
& & 23S-Reverse & AAGGCATCCACCATGTACGC & 67.00 \\
cpn60 & NC_008570 & cpn60-Forward & AAGATGCTGGAAGGCGTAAA & 63.50 \\
& & cpn60-Reverse & GTTGACGAAGTACGGGGAGA & 64.00 \\
gyrB & NC_008570 & gyrB-Forward & TACCCTGCTGCTGACCTTCT & 63.90 \\
& & gyrB-Reverse & AAGTCGTAGCTGAGCGGGTA & 63.70 \\
rpoD & NC_008570 & rpoD-Forward & GTGGTCTGCAGTTCCTGGAT & 64.10 \\
& & rpoD-Reverse & ATACGCTCACGGGTAACGTC & 63.80 \\
\hline
\end{tabular}


calculated for each isolate, and the different amounts of bacteria injected into fish in each treatment group were calculated according to their dilution factor. At least 5 different amounts (ranging from $1 \times 10^{4}$ to $2 \times$ $10^{9} \mathrm{CFU}$ fish $^{-1}$ ) of each isolate that kills 0 to $100 \%$ fish were administered to channel catfish (industry pool strain) though intraperitoneal (IP) injection. Channel catfish $(26.5 \pm 4.5 \mathrm{~g})$ naïve to $A$. hydrophila exposure were randomly obtained from stocks maintained at the USDA-ARS-Aquatic Animal Health Research Unit at Auburn, Alabama, and acclimated for $7 \mathrm{~d}$ prior to challenge. Acclimated fish were maintained in $57 \mathrm{l}$ glass aquaria with flow-through $\left(0.5 \mathrm{l} \mathrm{min}^{-1}\right)$ dechlorinated tap water and constant aeration with water temperature at $28^{\circ} \mathrm{C}$. The dissolved oxygen range was between 6 and $8 \mathrm{mg} \mathrm{l}^{-1}$. A 12:12 h light:dark cycle was maintained. Fish were fed daily with commercial Aquamax Grower at $4 \%$ of their body weight. After exposing catfish to A. hydrophila, mortalities were recorded daily for $14 \mathrm{~d}$ post exposure. The presence or absence of A. hydrophila in dead fish was determined by culturing anterior kidney samples on blood agar plates followed by biochemical analysis. Lethal doses that caused $50 \%$ mortality $\left(\mathrm{LD}_{50}\right)$ were calculated using PoloPlus probit and logit analysis software (LeOra Software). Virulence between different isolates was considered significantly different when the 95\% confidence intervals of $\mathrm{LD}_{50}$ values failed to overlap $(\mathrm{p} \leq 0.05)$.

\section{RESULTS AND DISCUSSION}

API 20E biochemical identification results of the 4 bacterial isolates revealed that all 4 isolates were Aeromonas hydrophila, which shared similar biochemical profiles as known A. hydrophila deposited into the Mini API strip reading system (Biomerieux). The 3 isolates from 2009 were positive for $\beta$-galactosidase, arginine dihydrolase, citrate utilization, indole production, acetoin production, gelatinase, glucose oxidation, mannitol oxidation, inositol oxidation, saccharose oxidation, arabinose oxidation, and cytochrome oxidase; they were negative for lysine decarboxylase, ornithine decarboxylase, $\mathrm{H}_{2} \mathrm{~S}$ production, urease, tryptophane deaminase, sorbitol oxidation, rhamnose oxidation, melibiose oxidation, and amygdalin oxidation. The 1998 Alabama isolate AL98-C1B had the same biochemical profile in the API 20E strip test, except that its reading of inositol oxidation and arabinose oxidation were both negative. Fatty acid methyl ester analysis by the MIDI microbial identification gas chromatography system revealed that all 3 isolates from 2009 had high similarity indices $(0.682,0.690,0.724$, respectively, for AL09-71, AL09-72, AL09-73) with A. hydrophila de- posited in the RCLN50 database of the microbial identification system. AL98-C1B had a lower similarity index (0.380) with $A$. hydrophila deposited in the RCLN50 database, suggesting that AL98-C1B is distantly related to the 3 isolates from 2009.

Sequencing results of PCR products obtained for 16S-23S ISR, cpn60, gyrB, and rpoD from the 4 Aeromonas hydrophila isolates were deposited in GenBank under accession numbers HM856359 to HM856374. Comparing the 2009 isolates and the 1998 AL98-C1B isolate with A. hydrophila ssp. hydrophila ATCC7966 (accession no. NC_008570), the 2009 isolates shared the highest homology with ATCC7966 (with homologies ranging from 94 to $95 \%$ with $16 \mathrm{~S}-23 \mathrm{~S}$ ISR, 96 to $98 \%$ with cpn60, $96 \%$ with $g y r B$, and $97 \%$ with $r p o D$ ). Sequences of AL98-C1B shared lower homology with ATCC7966 (63\% with 16S-23S ISR, 91\% with cpn60, $93 \%$ with $g y r B$, and $95 \%$ with $r p o D$ ). The 3 Alabama isolates from 2009 shared high homology with each other (16S-23S ISR shared 97 to $98 \%$ homology, cpn60 shared 98 to $99 \%$, and gyrB or $r p o D$ shared $99 \%$ ); however, they shared lower homology with AL98-C1B (63 to $64 \%$ with $16 \mathrm{~S}-23 \mathrm{~S}$ ISR, 90 to $91 \%$ with cpn60, $92 \%$ with $g y r B$, and $95 \%$ with rpoD). Pairwise homologies are given in Table 2 .

Mortalities were observed as early as $6 \mathrm{~h}$ post injection at a dose of $1.6 \times 10^{5} \mathrm{CFU}$ fish $^{-1}$ or higher following IP injection of channel catfish fingerlings with the 3 isolates from 2009, and the majority of the mortalities occurred within $24 \mathrm{~h}$ post injection. Cultures from dead fish were all confirmed to be Aeromonas hydrophila. The 2009 isolates were significantly $(p<0.05)$ more virulent than the 1998 isolate AL98-C1B based on both $\mathrm{LD}_{50}$ and $\mathrm{LD}_{95}$ values (Table 3). Based on $\mathrm{LD}_{50}$ values,

Table 2. Aeromonas hydrophila. Homology (\%) between sequences of different isolates. Full gene names as in Table 1

\begin{tabular}{|c|c|c|c|c|c|}
\hline Gene & Isolate & $\begin{array}{c}\text { AL09- } \\
71\end{array}$ & $\begin{array}{c}\text { AL09- } \\
72\end{array}$ & $\begin{array}{c}\text { AL09- } \\
73\end{array}$ & $\begin{array}{c}\text { AL98- } \\
\text { C1B }\end{array}$ \\
\hline \multirow[t]{4}{*}{$16 \mathrm{~S}$ ISR } & AL09-72 & 97 & & & \\
\hline & AL09-73 & 98 & 98 & & \\
\hline & AL98-C1B & 63 & 64 & 63 & \\
\hline & ATCC7966 & 94 & 95 & 95 & 63 \\
\hline \multirow[t]{4}{*}{ срп60 } & AL09-72 & 99 & & & \\
\hline & AL09-73 & 98 & 98 & & \\
\hline & AL98-C1B & 91 & 91 & 90 & \\
\hline & ATCC7966 & 98 & 98 & 96 & 91 \\
\hline \multirow[t]{4}{*}{ gyrB } & AL09-72 & 99 & & & \\
\hline & AL09-73 & 99 & 99 & & \\
\hline & AL98-C1B & 92 & 92 & 92 & \\
\hline & ATCC7966 & 96 & 96 & 96 & 93 \\
\hline \multirow[t]{4}{*}{$r p o D$} & AL09-72 & 99 & & & \\
\hline & AL09-73 & 99 & 99 & & \\
\hline & AL98-C1B & 95 & 95 & 95 & \\
\hline & ATCC7966 & 97 & 97 & 97 & 95 \\
\hline
\end{tabular}


Table 3. Aeromonas hydrophila. $\mathrm{LD}_{50}$ and $\mathrm{LD}_{95}$ values (in colony forming units per fish) of the 4 isolates to channel catfish by intraperitoneal (IP) injection. Different letters within columns indicate that the virulences of the A. hydrophila strains were significantly different from each other because the $95 \%$ confidence intervals (CI) failed to overlap

\begin{tabular}{|lccrl|}
\hline Strain & $\mathrm{LD}_{50}(95 \% \mathrm{CI})$ & $\mathrm{LD}_{95}(95 \% \mathrm{CI})$ & Slope (SE) & $\chi^{2}$ \\
\hline AL09-71 & $1.1 \times 10^{5}\left(6.2 \times 10^{4}-2.1 \times 10^{5}\right)^{\mathrm{A}}$ & $7.0 \times 10^{5}\left(3.1 \times 10^{5}-2.1 \times 10^{7}\right)^{\mathrm{A}}$ & $3.04(0.68)$ \\
AL09-72 & $1.9 \times 10^{5}\left(1.3 \times 10^{5}-2.5 \times 10^{5}\right)^{\mathrm{A}}$ & $4.8 \times 10^{5}\left(4.8 \times 10^{5}-1.8 \times 10^{6}\right)^{\mathrm{A}}$ & $5.11(0.53)$ & 1.11 \\
AL09-73 & $1.3 \times 10^{5}\left(8.9 \times 10^{4}-1.8 \times 10^{5}\right)^{\mathrm{A}}$ & $4.8 \times 10^{5}\left(3.0 \times 10^{5}-1.8 \times 10^{6}\right)^{\mathrm{A}}$ & $3.76(0.78)$ & 0.49 \\
AL98-C1B & $2.3 \times 10^{7}\left(1.2 \times 10^{7}-4.2 \times 10^{7}\right)^{\mathrm{B}}$ & $2.0 \times 10^{8}\left(9.1 \times 10^{7}-1.6 \times 10^{9}\right)^{\mathrm{B}}$ & $3.03(0.49)$ & 1.30 \\
\hline
\end{tabular}

AL09-71 was the most virulent 2009 isolate, followed by AL09-73 and AL09-72 (Table 3). However, the difference in virulence among the 3 isolates was not significantly different.

Precise identification of pathogen is a prerequisite to successful control of disease outbreak. Identification of Aeromonas at the species level by routine procedures involves many difficulties because of the absence of a unified identification key and the lack of agreement between biochemical and genetic identification schemes (Soler et al. 2004, Ormen et al. 2005). Using biochemical identification methods, we were able to identify the 3 isolates from 2009 as A. hydrophila and confirmed that they differed from AL98-C1B, but we were unable to determine whether the 2009 isolates were the same or different by biochemical methods. Sequencing of the 16S-23S rDNA ISR is considered a robust and sensitive taxonomic tool which is widely used in bacterial taxonomy (Martínez-Murcia et al. 2005, Tazumi et al. 2009). Sequence comparisons based on 16S-23S rDNA ISRs of the 4 isolates revealed that the 2009 isolates were closely related to each other, but very distantly related to AL98-C1B, suggesting that AL98-C1B and the 3 more recent isolates were different strains. Sequences of cpn60 of the 4 isolates shared higher homology (91 to $98 \%$ ) with cpn60 of the ATCC7966 strain than sequences of ISR of the 4 isolates (63 to $95 \%$ homology with ATCC7966), suggesting that ISR sequences of different A. hydrophila were more divergent than cpn60 sequences and that ISR might be a better taxonomic tool to differentiate closely related Aeromonas species. Nonetheless, both ISR and cpn60 sequences revealed the same relationships among the 4 isolates, suggesting that both ISR and cpn60 were appropriate in differentiating the 4 isolates from Alabama.

The $g y r B$ and $r p o D$ sequences of the 2009 isolates also differentiated from the AL98-C1B isolate (Table 2). However, among the 2009 isolates, gyrB and $r p o D$ shared $99 \%$ homology, suggesting that both gyrB and $r p o D$ are very conserved house-keeping genes, which might not be more appropriate molecular markers to differentiate closely related Aeromonas species.

Our data suggested that the 2009 isolates were highly virulent to channel catfish, which might explain why so many fish were killed in the 2009 disease outbreak in west Alabama. Virulence studies of the 4 isolates revealed that most infected fish died within $24 \mathrm{~h}$ post exposure, suggesting that rapid-acting virulence factors might play an important role in the disease. The identities of the virulence factors and their exact roles in Aeromonas disease merit further study.

Acknowledgements. We thank D. Xu (USDA-ARS) and V. Panangala (USDA collaborator) for critical reviews of the manuscript; B. Hemstreet (Alabama Fish Farming Center), J. Terhune (Auburn University), and J. Bebak (USDA-ARS) for obtaining the 2009 isolates of Aeromonas hydrophila; B. Peterman (USDA-ARS) for technical support; and B. Scheffler and F. Liu (USDA-ARS-Catfish Genetics Research Unit) for sequencing work. We also thank the management team of the Aquatic Animal Health Research Unit for daily care and management of the fish. This study was supported by the USDA/ARS CRIS project no. 6420-32000-024-00D. The use of trade, firm, or corporate names in this publication is for the information and convenience of the reader. Such use does not constitute an official endorsement or approval by the United States Department of Agriculture or the Agricultural Research Service of any product or service to the exclusion of others that may be suitable.

\section{LITERATURE CITED}

Abd-El-Rhman AM (2009) Antagonism of Aeromonas hydrophila by propolis and its effect on the performance of Nile tilapia, Oreochromis niloticus. Fish Shellfish Immunol 27: $454-459$

Azad IS, Rajendran KV, Rajan JJS, Vijayan KK, Santiago TC (2001) Virulence and histopathology of Aeromonas hydrophila (Sah 93) in experimentally infected tilapia, Oreochromis mossambicus (L.). J Aquac Trop 16:265-275

Esteve C, Amaro C, Toranzo AE (1994) O-serogrouping and surface components of Aeromonas hydrophila and Aeromonas jandaei pathogenic for eels. FEMS Microbiol Lett 117:85-90

Fang HM, Ge R, Sin YM (2004) Cloning, characterisation and expression of Aeromonas hydrophila major adhesin. Fish Shellfish Immunol 16:645-658

Harikrishnan R, Nisha Rani M, Balasundaram C (2003) Hematological and biochemical parameters in common carp, Cyprinus carpio, following herbal treatment for Aeromonas hydrophila infection. Aquaculture 221:41-50

> Harikrishnan R, Balasundaram C, Heo MS (2009) Effect of chemotherapy, vaccines and immunostimulants on innate immunity of goldfish infected with Aeromonas hydrophila. Dis Aquat Org 88:45-54 
Hemstreet B (2010) An update on Aeromonas hydrophila from a fish health specialist for summer 2010. Catfish J $24: 4$

Holt JG, Krieg NR, Sneath PHA, Staley JT (1994) Bergey's manual of determinative bacteriology, 9th edn. Williams \& Wilkins, Baltimore, MD, p 255-273

Irianto A, Robertson PA, Austin B (2003) Oral administration of formalin-inactivated cells of Aeromonas hydrophila A351 controls infection by atypical $A$. salmonicida in goldfish, Carassius auratus (L.). J Fish Dis 26:117-120

Jeney Z, Rácz T, Thompson KD, Poobalane S, Ardó L, Adams A, Jeney G (2009) Differences in the antibody response and survival of genetically different varieties of common carp (Cyprinus carpio L.) vaccinated with a commercial Aeromonas salmonicida/A. hydrophila vaccine and challenged with A. hydrophila. Fish Physiol Biochem 35: $677-682$

Karunasagar I, Rosalind GM, Karunasagar I, Gopal Rao K (1989) Aeromonas hydrophila septicaemia of Indian major carps in some commercial fish farms of West Godavari District, Andhra Pradesh. Curr Sci 58:1044-1045

- Majumdar T, Datta S, Ghosh D, Dutta S, Chakraborty A, Goswami R, Mazumder S (2007) Role of virulence plasmid of Aeromonas hydrophila in the pathogenesis of ulcerative disease syndrome in Clarias batrachus. Indian J Biochem Biophys 44:401-406

Martínez-Murcia AJ, Soler L, Saavedra MJ, Chacón MR, Guarro J, Stackebrandt E, Figueras MJ (2005) Phenotypic, genotypic, and phylogenetic discrepancies to differentiate Aeromonas salmonicida from Aeromonas bestiarum. Int Microbiol 8:259-269

Mastan SA, Qureshi TA (2001) Role of bacteria in the epizootic ulcerative syndrome (EUS) of fishes. J Environ Biol 22:187-192

Miñana-Galbis D, Farfàn M, Lorén JG, Fusté MC (2010) The reference strain Aeromonas hydrophila CIP 57.50 should be reclassified as Aeromonas salmonicida CIP 57.50. Int J Syst Evol Microbiol 60:715-717

Editorial responsibility: Catherine Collins, Aberdeen, UK
Nielsen ME, Høi L, Schmidt AS, Qian D, Shimada T, Shen JY, Larsen JL (2001) Is Aeromonas hydrophila the dominant motile Aeromonas species that causes disease outbreaks in aquaculture production in the Zhejiang Province of China? Dis Aquat Org 46:23-29

> Ormen O, Granum PE, Lassen J, Figueras MJ (2005) Lack of agreement between biochemical and genetic identification of Aeromonas spp. APMIS 113:203-207

> Panangala VS, Shoemaker CA, Van Santen VL, Dybvig K, Klesius PH (2007) Multiplex-PCR for simultaneous detection of 3 bacterial fish pathogens, Flavobacterium columnare, Edwardsiella ictaluri, and Aeromonas hydrophila. Dis Aquat Org 74:199-208

Soler L, Yáñez MA, Chacon MR, Aguilera-Arreola MG, Catalán V, Figueras MJ, Martínez-Murcia AJ (2004) Phylogenetic analysis of the genus Aeromonas based on two housekeeping genes. Int J Syst Evol Microbiol 54:1511-1519

Tazumi A, Ono S, Sekizuka T, Moore JE, Millar BC, Matsuda M (2009) Molecular characterization of the sequences of the $16 \mathrm{~S}-23 \mathrm{~S}$ rDNA intergenic spacer region (ISR) from isolates of Taylorella asinigenitalis. BMC Res Notes 2:33

Tellez-Bañuelos MC, Santerre A, Casas-Solis J, Zaitseva G (2010) Endosulfan increases seric interleukin-2 like (IL2L) factor and immunoglobulin M (IgM) of Nile tilapia (Oreochromis niloticus) challenged with Aeromonas hydrophila. Fish Shellfish Immunol 28:401-405

Thorpe JE, Roberts RJ (1972) Aeromonad epidemic in brown trout (Salmo trutta (L.)). J Fish Biol 4:441-541

Ullal AJ, Litaker RW, Noga EJ (2008) Antimicrobial peptides derived from hemoglobin are expressed in epithelium of channel catfish (Ictalurus punctatus, Rafinesque). Dev Comp Immunol 32:1301-1312

> Yin G, Ardó L, Thompson KD, Adams A, Jeney Z, Jeney G (2009) Chinese herbs (Astragalus radix and Ganoderma lucidum) enhance immune response of carp, Cyprinus carpio, and protection against Aeromonas hydrophila. Fish Shellfish Immunol 26:140-145

Submitted: August 11, 2010; Accepted: January 11, 2011 Proofs received from author(s): April 7, 2011 